\title{
気管支喘息における血清 $\operatorname{IgE}$ と $\mathrm{IgG}_{4}$ 値
}

\section{の関連について}

\author{
谷 崎勝朗・貴 谷光 - 岡 崎守宏 \\ 御 船 尚志・光 延 文 裕・木 村 郁 郎*
}

Jpn. J. Clin. Immun., 15 (5) : 459 466, 1992.

\section{Correlation between serum levels of $\operatorname{IgE}$ and $\operatorname{IgG}_{4}$ in patients with bronchial asthma}

\author{
Yoshiro Tanizaki, Hikaru Kitani, Morihiro Okazaki, \\ Takashi Mifune, Fumihiro Mitsunobu and Ikuro Kimura*
}

\begin{abstract}
Division of Medicine, Misasa Medical Branch, Okayama University Medical School *second Department of Medicine, Okayama University Medical School
\end{abstract}

\section{【Summary】}

A correlation between serum levels of $\mathrm{IgE}$ and $\mathrm{IgG}_{4}$ was examined in 79 patients with bronchial asthma. High levels of $\operatorname{IgG}_{4}$ were not always correlated to high levels of $\operatorname{IgE}$ in all subjects with asthma. $\mathrm{IgG}_{4}$ levels tended to increase as IgE levels increased in patients over age 60 , but not in those under age 59 . The results show that serum $\operatorname{IgG}_{4}$ levels are associated with serum IgE levels in patients over age 60 and are related to patient age in all subjects with asthma.

\author{
Key words : IgE, \\ $\mathrm{IgG}_{4}$, \\ patient age, \\ bronchial asthma
}

\section{【概 要】}

血清 $\mathrm{IgE} お よ ひ ゙ ~ \mathrm{IgG}_{4}$ は, 気管支喘息における主要な反応系である即時型アレルギー反応に関与する免疫グロ ブリンと考えられている.このうち，IgEは即時型アレルギー反応をひき起こす抗体として知られているが， $\mathrm{IgG}_{4}$ については, 即時型アレルギー反応に対して遮断抗体として作用するのか, 反応の増強因子として作用す るのか, なお議論が多い. 一方, in vitro の系では, 両者とも IL-4 刺激により B細胞での産生六進が見られる. 本論文では，気管支喘息における血清中 $\mathrm{IgE}$ および $\mathrm{IgG}_{4}$ 值の関連について検討を加えた. 
対象および方法：対象としては気管支喘息 79 例を選んだ。血清 IgE 値は RIST 法により，またIgG 值は ELISA 法により測定した。

成績：血清 IgE 值は 19 歳までの年齢層で高く，30〜69 歳の年齡層に比べ有意の高値を示した。一方，70 歳以 上の症例では, 血清 $\mathrm{IgE}$ 值は増加傾向を示し， 50 69 歳の年齢層に比べ有意に高い值を示した。

血清 $\mathrm{IgG}_{4}$ は, $0 \sim 9$ 歳の年齢層で 20〜 49 歳の年齢層に比べ有意に低く, 70 歳以上の年齢層では, $60 \sim 69$ 歳 の年齢層に比べ有意に高い傾向を示した。しかし，10６9歳の年齢層では，各年齢層間に有意の差は見られな かった.

血清 $\mathrm{IgG}_{4}$ と $\mathrm{IgE}$ 值は，60 歳以上の年齢層では有意の相関が見られ，これらの症例では，血清 $\mathrm{IgE}$ 值が高くな るにつれて， $\mathrm{IgG}_{4}$ も増加する傾向が見られた。しかし，59歳以下の症例では $\mathrm{IgE} と \mathrm{IgG}_{4}$ 值の間の関連は見ら れなかった。

血清 $\mathrm{IgG}_{4}$ 值が $100 \mathrm{mg} / \mathrm{d} l$ 以上を示す 13 症例の検討では， 8 例（61.5\%）が 60 歳以上，9例（69.2\%）が血 清 $\mathrm{IgE}$ が $400 \mathrm{IU} / \mathrm{m} l$ 以上であった.

これらの結果は, 血清 $\operatorname{IgG}_{4}$ は, 60 歳以上の症例では血清 $\operatorname{IgE}$ 值と, また全症例の検討では年齢と, 関連を有 していることを示している.

\section{Introduction}

It is widely accepted that the immediate allergic reaction, in which primarily $\mathrm{IgE}$ and $\mathrm{IgG}_{4}$ antibodies participate, plays an important role in the mechanism of onset of bronchial asthma. The role of $\operatorname{IgE}$ antibodies is well defined: They induce the release of chemical mediators from tissue mast cells and blood basophils by bridging IgE receptors on the membranes of these cells ${ }^{1 \sim 3)}$. $\operatorname{IgG}_{4}$ is thought to be involved in atopic disorders; however, whether the action of $\mathrm{IgG}_{4}$ antibodies in the immediate allergic reaction is protective or anaphylactic is a major point of contention ${ }^{4 \sim 8)}$.

Several investigators have found high levels of $\mathrm{IgE}$ and $\mathrm{IgG}_{4}$, but normal levels of $\operatorname{IgG}_{1}, \operatorname{IgG}_{2}$ and $\mathrm{IgG}_{3}$ in patients with atopic eczema and bronchial asthma ${ }^{9-11}$. Recent studies have demonstrated significantly higher levels of $\mathrm{IgG}_{1}$ and $\mathrm{IgG}_{4}$ in infants with elevated IgE levels than in those with lower levels $^{12)}$. Furthermore, interleukin 4 (IL-4), which induces human $B$ cells to secrete significant amounts of $\operatorname{IgE}^{13)}$, also induces $\operatorname{IgG}_{4}$ production, but has no effect on the production of $\operatorname{IgG}_{1}, \operatorname{IgG}_{2}$, and $\mathrm{IgG}_{3}$ by $\mathrm{B}$ cells ${ }^{14-16)}$. To date, however, few studies have addressed correlations between serum levels of $\mathrm{IgE}$ and $\mathrm{IgG}_{4}$ in adult bronchial asthma patients.

In the present study, we examined the correlation between levels of serum IgE and $\operatorname{IgG}_{4}$ in bronchial asthma patients of various ages to compare differences in these levels.

\section{Subjects and Methods}

The subjects were 79 bronchial asthma patients (47 females and 32 males; mean age 47.4 years, range 6 to 80 ). The mean level of serum IgE was 456 $\mathrm{IU} / \mathrm{m} l$ (range, $8 \sim 2,626 \mathrm{IU} / \mathrm{m} l$ ). Specific IgE antibodies to inhalant allergens were found in 33 of the 79 patients $(41.8 \%)$. The subjects were divided into eight groups according to age : $0 \sim 9,10 \sim 19,20 \sim 29$, $30 \sim 39,40 \sim 49,50 \sim 59,60 \sim 69$ and $70+$ years. They were also divided into five groups according to serum IgE level : 0 100, 101 200, 201 500, 501 1,000 , and $1,001+\mathrm{IU} / \mathrm{m} l$. Bronchial asthma was clinically diagnosed according to previously defined criteria ${ }^{177}$.

Serum $\mathrm{IgG}_{4}$ levels were measured by an enzymelinked immunosorbent assay (ELISA), using a modified method ${ }^{18 \sim 20}$ based on that described by Engvall et al. ${ }^{21}$. The wells of polystyrene microtiter plates were coated overnight with $200-\mu l$ samples of monoclonal anti-IgG 4 (Yamasa Shoyu Co), at a 1 : 1,000 dilution in $0.05 \mathrm{M}$ phosphate buffer solution ( $\mathrm{pH}$ 7.4). After three washes with $0.05 \mathrm{M}$ phosphate buffered saline (PBS), $250 \mu l$ of PBS containing $0.5 \%$ bovine serum albumin (BSA) was added to the wells and they were incubated for $2 \mathrm{hr}$ at room temperature. After three washes with PBS 
containing Tween 20 (PBS-TW 20), $200 \mu l$ serum samples, at a $1: 20,000$ dilution in PBS-TW 20 containing $0.1 \%$ bovine $\gamma$-globulin, were added to the wells, which were then incubated at $4^{\circ} \mathrm{C}$ overnight. After the wells were washed with PBSTW $20,200 \mu l$ of peroxidase-conjugated anti-mouse IgE (Capple Lab.), at a $1: 10,000$ dilution in PBSTW 20 containing $1 \% \gamma$-globulin, was added to the wells, and they were incubated for $2 \mathrm{hr}$ at room temperature. After a further washing, $200 \mu l$ of the substrate, o-phenylenediamine, was added to the wells and they were incubated for $30 \mathrm{~min}$ at room

Table 1 Differences in serum levels of IgE and $\mathrm{IgG}_{4}$ in subjects classified by age

\begin{tabular}{cccl}
\hline \multirow{2}{*}{$\begin{array}{c}\text { Age, } \\
\text { years }\end{array}$} & $\begin{array}{c}\text { No of } \\
\text { patients }\end{array}$ & \multicolumn{2}{c}{ Serum levels } \\
\hline $0 \sim 9$ & 5 & $1,298 \pm 642^{\text {*abcd }}$ & $16.2 \pm 4.2^{\text {jk1 }}$ \\
\hline $0 \sim 96$ & $\operatorname{IgG}_{4}(\mathrm{mg} / \mathrm{d} l)$ \\
$10 \sim 19$ & 8 & $1,341 \pm 819^{\text {erg }}$ & $62.3 \pm 45.2$ \\
$20 \sim 29$ & 5 & $1,026 \pm 787$ & $57.4 \pm 28.9^{\mathrm{j}}$ \\
$30 \sim 39$ & 8 & $545 \pm 571^{\mathrm{a}}$ & $60.5 \pm 42.7^{\mathrm{k}}$ \\
$40 \sim 49$ & 8 & $343 \pm 370^{\mathrm{be}}$ & $56.5 \pm 28.3^{\mathrm{1}}$ \\
$50 \sim 59$ & 14 & $285 \pm 391^{\mathrm{chh}}$ & $57.4 \pm 55.4$ \\
$60 \sim 69$ & 17 & $312 \pm 255^{\mathrm{dgl}}$ & $54.2 \pm 52.9^{\mathrm{m}}$ \\
$70+$ & 14 & $836 \pm 787^{\mathrm{hl}}$ & $98.4 \pm 66.9^{\mathrm{m}}$ \\
\hline
\end{tabular}

*Mean \pm SD. $a, h, k$ and $m, p<0.05 ; b, f$ and $l$, p $<0.01 ; c, d, e, f, g$ and j. $p<0.001 ; i, p<0.02$. temperature. Color development was stopped by adding $50 \mu l$ of $4 \mathrm{~N} \mathrm{H}_{2} \mathrm{SO}_{4}$, and the $\mathrm{OD}$ was determined at $490 \mathrm{~nm}$. These assays were carried out in duplicate. Serum $\mathrm{IgG}_{4}$ was expressed as $\mathrm{mg} / \mathrm{d} l$.

Serum IgE levels were determined by a radioimmunosorbent test (RIST), and the results were expressed as $\mathrm{IU} / \mathrm{m} l$. The levels of specific $\mathrm{IgE}$ antibodies to inhalant allergens were evaluated by a radioallergosorbent test (RAST). The results were expressed as a score, a score of $2+$ or more being regarded as positive.

Statistically significant differences of the mean were assessed using Student's unpaired t test. The levels of significance were expressed as $p$ values.

\section{Results}

IgE levels were higher in patients younger than 29 , and the levels tended to decrease in patients between the ages of 30 and 69 . These levels were significantly higher in patients between the ages of 10 and 19 than in those between 30 and $39(p<0.05)$ and those between 40 and 69 . A significantly higher level of $\operatorname{IgE}$ was found in patients over the age of 70 compared with levels in patients between 60 and 69 $(p<0.02)$, between 50 and $59, \quad(p<0.05)$ and between 40 and $49(p<0.001) . \operatorname{IgG}_{4}$ levels, in con-

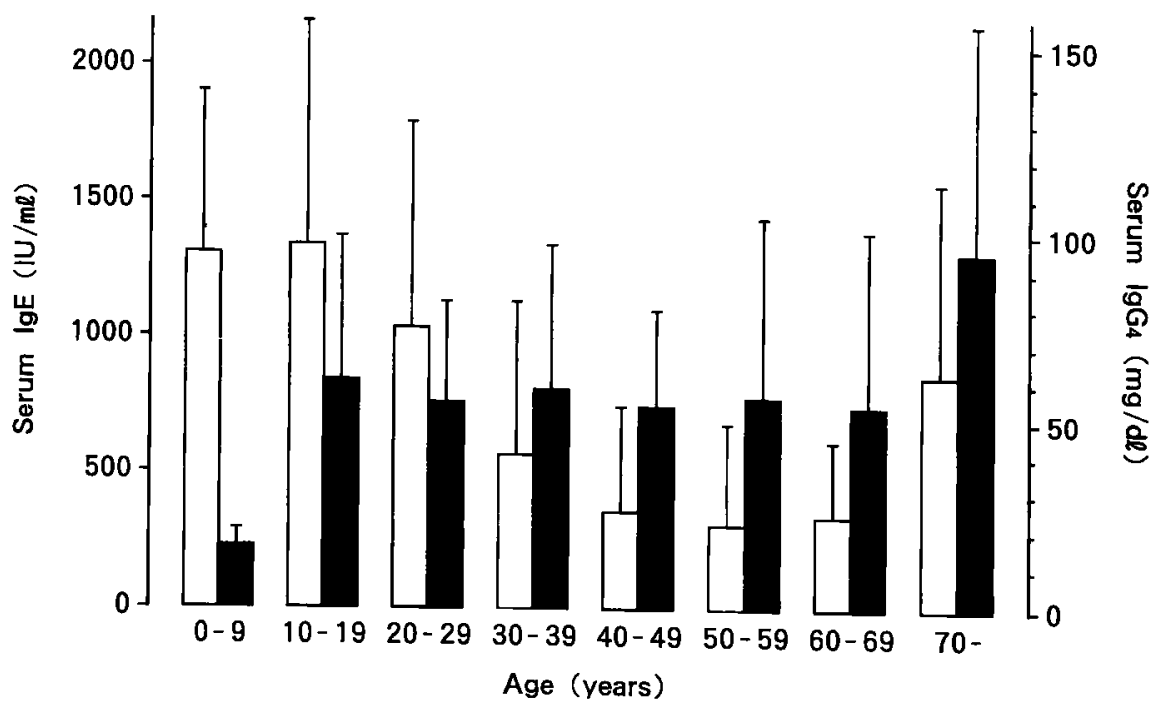

Fig. 1 Serum Levels of $\operatorname{IgE}(\square)$ and $\operatorname{IgG}_{4}(\boldsymbol{D})$ in bronchial asthma patients in relation to age. Vertical bars represent mean \pm SD. 
Table 2 Correlation between serum levels of IgE and $\mathrm{IgG}_{4}$ in bronchial asthma patients

\begin{tabular}{cccc}
\hline Serum & No of & \multicolumn{2}{c}{ Serum IgG $(\mathrm{mg} / \mathrm{d} l)$} \\
$\mathrm{IgE}(\mathrm{IU} / \mathrm{m} l)$ & patients & \multicolumn{1}{c}{ Mean \pm SD } & \multicolumn{1}{c}{ Range } \\
\hline $0 \sim 100$ & 18 & $40.6 \pm 26.6 \mathrm{a}$ & $6 \sim 94$ \\
$101 \sim 200$ & 13 & $62.9 \pm 48.3$ & $8 \sim 150$ \\
$201 \sim 500$ & 17 & $71.7 \pm 50.8 \mathrm{a}$ & $20 \sim 210$ \\
$501 \sim 1,000$ & 15 & $64.7 \pm 60.8$ & $11 \sim 200$ \\
$1,001+$ & 16 & $70.4 \pm 68.1$ & $14 \sim 280$ \\
\hline
\end{tabular}

a, $\mathrm{p}<0.05$.

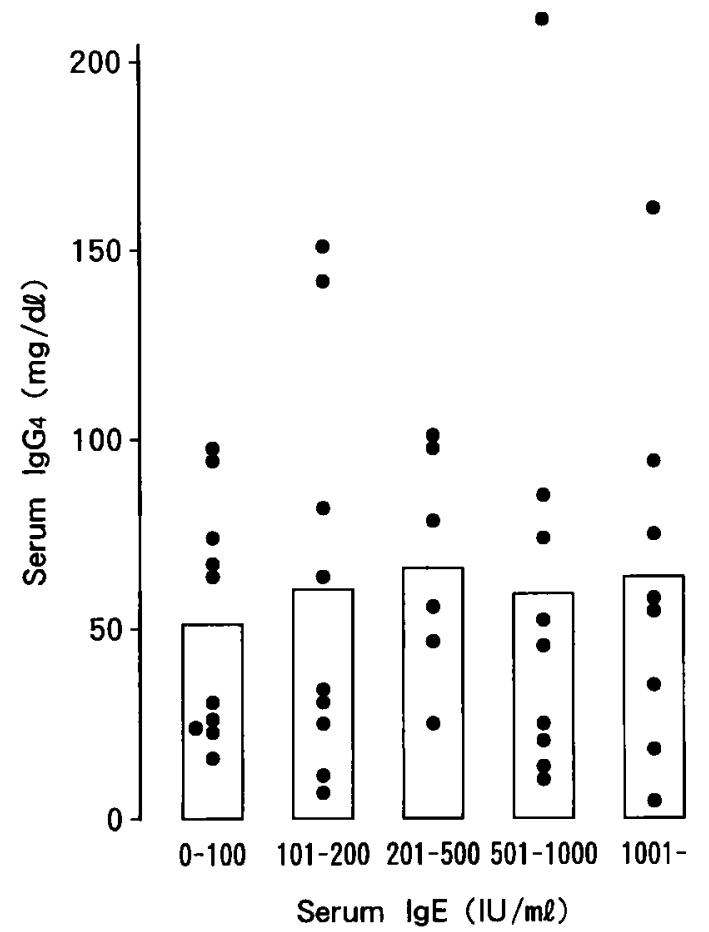

Fig. 2 Correlation between serum levels of IgE and $\mathrm{IgG}_{4}$ in patients between the ages of 10 and 59 . Vertical columns represent the mean of each group classified by serum IgE levels.

trast, were significantly lower in patients younger than 9 compared with the levels in patients between 20 and $29(p<0.01)$, between 30 and $39(p<0.05)$ and between 40 and $49(p<0.01)$. No significant difference in serum $\mathrm{IgG}_{4}$ levels was found among patients aged from 10 to 69 . Elevated levels of $\mathrm{IgG}_{4}$ were found in patients over age 70 , in whom these levels were significantly higher than those in

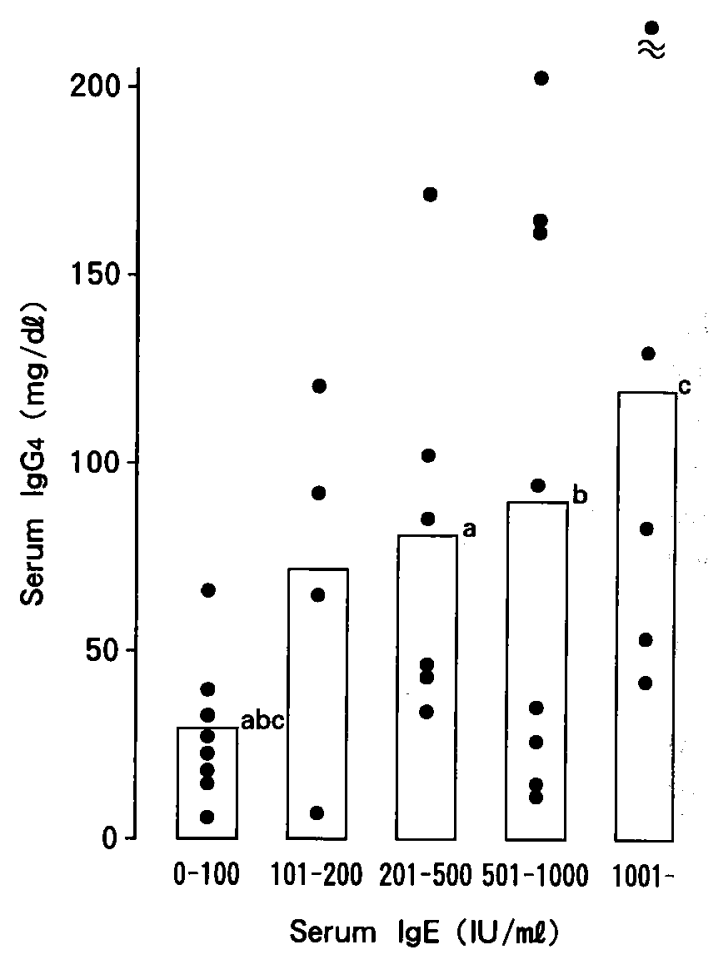

Fig. 3 Correlation between serum levels of $\mathrm{IgE}$ and $\mathrm{IgG}_{4}$ in patients over the age of 60 . Vertical columns represent the mean of each group classified by serum IgE levels. a, $\mathrm{p}<0.01 ; \mathrm{b}, \mathrm{p}<$ $0.05 ; \mathrm{c}, \mathrm{p}<0.02$.

patients between 60 and $69(\mathrm{p}<0.05)$ (Table 1, Fig. 1).

Levels of $\mathrm{IgG}_{4}$ were not always more elevated in patients with high levels of serum IgE in the subjects overall, although there was a significant difference between $\mathrm{IgG}_{4}$ levels in patients with serum $\mathrm{IgE}$ levels of $0 \sim 100 \mathrm{IU} / \mathrm{m} l$ and $201 \sim 500 \mathrm{IU} / \mathrm{m} l(\mathrm{p}<$ 0.05 ) (Table 2). We examined the IgE and $\mathrm{IgG}_{4}$ levels in patients between the ages of 10 and 59 to determine whether these levels were correlated. No significant correlation was observed (Fig.2).

$\mathrm{IgG}_{4}$ levels in patients over the age of 60 tended to increase as levels of $\mathrm{IgE}$ increased. Significantly higher $\mathrm{IgG}_{4}$ levels were found in patients with high serum IgE levels (between 201 and $500 \mathrm{IU} / \mathrm{m} l(\mathrm{p}<$ $0.01)$, between 501 and $1,000 \mathrm{IU} / \mathrm{m} l(\mathrm{p}<0.05)$, and over $1,001 \mathrm{IU} / \mathrm{m} l(\mathrm{p}<0.02)$, than in those with low 
Table 3 Correlation between serum levels of IgE and $\mathrm{IgG}_{4}$ in patients with high $\mathrm{IgG}_{4}$ level

\begin{tabular}{cccccc}
\hline $\begin{array}{c}\text { Case } \\
\text { no }\end{array}$ & $\begin{array}{c}\text { Age, } \\
\text { years }\end{array}$ & Sex & $\begin{array}{c}\text { IgG } \\
(\mathrm{mg} / \mathrm{d} l)\end{array}$ & $\begin{array}{c}\text { IgE } \\
(\mathrm{IU} / \mathrm{m} l)\end{array}$ & $\begin{array}{c}\text { Inhalant } \\
\text { allergens }\end{array}$ \\
\hline 1 & 71 & F & 280 & 1,152 & - \\
2 & 52 & F & 210 & 578 & - \\
3 & 65 & M & 200 & 790 & - \\
4 & 70 & M & 170 & 485 & - \\
5 & 64 & F & 160 & 724 & - \\
6 & 72 & M & 160 & 673 & HD 2+ \\
7 & 17 & F & 160 & 1,930 & HD 2+ \\
8 & 50 & F & 150 & 195 & HD 2+ \\
9 & 34 & F & 140 & 182 & - \\
10 & 77 & F & 128 & 2,007 & JC 2+ \\
11 & 80 & M & 120 & 177 & - \\
12 & 42 & M & 100 & 445 & JC 2+ \\
13 & 62 & F & 100 & 292 & - \\
\hline
\end{tabular}

HD, house dust ; JC, Japanese cedar.

serum IgE levels (between 0 and $100 \mathrm{IU} / \mathrm{m} l$ ) (Fig. 3).

Characteristics of patients with high serum $\mathrm{IgG}_{4}$ (over $100 \mathrm{mg} / \mathrm{d} l$ ) were analyzed in relation to their age and serum IgE levels. Of the 13 patients with high $\operatorname{IgG}_{4}$, eight (61.5\%) were over the age of 60 , and nine $(69.2 \%)$ had over $400 \mathrm{IU} / \mathrm{m} l$ of serum $\mathrm{IgE}$. These results revealed that serum $\mathrm{IgG}_{4}$ levels tended to be increased in relation to high serum IgE levels and increasing patient age (Table 3).

\section{Discussion}

IgE is well defined as the antibody, which induces the immediate allergic reaction ${ }^{1 \sim 3)}$ that plays the major role in the pathology of bronchial asthma. In accordance with such generally accepted views of the allergic reaction, some attempts have been made to distinguish allergic (extrinsic) from nonallergic asthma (intrinsic) ${ }^{22)}$. $\operatorname{lgG}_{4}$, in contrast to $\mathrm{IgE}$, was at first identified as a blocking antibody observed after immunotherapy with offending allergens ${ }^{4,5)}$. At present, however, there are some differences of opinion as to whether the role of $\mathrm{IgG}_{4}$ in the immediate type of immune response is anaphylactic or protective ${ }^{6 \sim 8,23)}$.

Some correlations between the serum levels of
IgE and $\mathrm{IgG}_{4}$ have been demonstrated by several investigators $^{9-12}$. Lilja et al. showed a weak positive correlation between $\mathrm{IgE}$ and $\mathrm{IgG}_{4}$ in infants at 18 months of age ${ }^{12)}$. This parallelism in IgE and IgG response has also been found in non-atopics and in patients with helminthiasis ${ }^{24,25)}$. It has been suggested that interleukin 4 (IL-4) derived from $T$ cells stimulates $B$ cells to secrete increased amounts of $\left.\mathrm{Ig} \mathrm{E}^{13,26 \sim 28}\right)$. IL-4 also induces the production of $\mathrm{IgG}_{4}$, but not that of $\operatorname{IgG}_{1}, \operatorname{IgG}_{2}$ or $\operatorname{IgG}_{3}{ }^{16,29}$. Moreover, It has been demonstrated that there is a clear difference in the capacity of structurally related allergens to stimulate the $\mathrm{IgE}$ and $\mathrm{IgG}_{4}$ response $^{30,31)}$. It has been revealed that $\mathrm{IgE}$ is synthesized predominantly in the lymphoid tissue of the respiratory tract, while $\mathrm{IgG}_{4}$ is synthesized predominantly in the intestinal lymphoid tissue ${ }^{8,32)}$.

In this study, elevated levels of IgE and $\operatorname{IgG}_{4}$ were observed in patients over age 70 , and a rise of $\mathrm{IgG}_{4}$ associated with elevated levels of $\mathrm{IgE}$ was found in those over age 60 . There was, however, no relationship between IgE and $\mathrm{IgG}_{4}$ levels in young children under age 9 . In these subjects (mean age, 7.6 years), $\mathrm{IgG}_{4}$ levels were rather lower than those in subjects over age 10. In patients between ages of 10 and 19 , serum $\mathrm{IgG}_{4}$ levels tended to increase in asthma patients with atopic dermatitis. Raised serum $\mathrm{IgG}_{4}$ levels were not always associated with the rise of $\operatorname{IgE}$ in patients between 10 and 59. Our findings from this study show that there was a relationship between the serum levels of $\mathrm{IgE}$ and $\mathrm{IgG}_{4}$ in asthma patients over age 60 , but not in those under age 59 . Analysis of the findings in patients with high $\mathrm{IgG}_{4}$ levels (over $100 \mathrm{mg} / \mathrm{d} l$ ) showed that patients over age 60 often had raised serum levels of both $\operatorname{IgE}$ and $I_{g G_{4}}$, suggesting that the synthesis of both these immunoglobulins is related to age in asthmatic patients. It was not clear from this study why raised serum levels of both $\mathrm{IgE}$ and $\mathrm{IgG}_{4}$ were found only in asthma patients over age 60. Furthermore, the clinical significance of serum $\mathrm{IgG}_{4}$ in asthma patients was not known. Further studies are needed to clarify the correlation between serum levels of $\operatorname{IgE}$ and $\mathrm{IgG}_{4}$, including clinical significance of 
serum $\operatorname{IgG}_{4}$ in asthma patients.

\section{Conclusion}

The possible correlation between serum levels of $\mathrm{IgE}$ and $\mathrm{IgG}_{4}$ was examined in 79 bronchial asthma patients. The levels of $\mathrm{IgE}$ were significantly higher in patients younger than 29 compared with levels in patients aged between 30 and 69 , in whom the $\operatorname{IgE}$ levels was not so increased. The serum IgE levels was significantly elevated in patients over the age of 70 compared with the level in those between 60 and $69(p<0.02)$. The level of $\operatorname{IgG}_{4}$, in contrast, was significantly lower in patients younger than 9 compared with the level in those aged between 20 and $29(p<0.01)$. Significantly higher levels of $\operatorname{IgG}_{4}$ were found in patients over age 70 compared with the levels in those between 60 and $69(\mathrm{p}<0.05)$. High levels of $\mathrm{IgG}_{4}$ were not always correlated to high levels of IgE. IgG 4 levels tended to increase as IgE levels increased in patients over age 60 , but not in those under age 59 . Of the 13 patients with high $\mathrm{IgG}_{4}$ (over $\left.100 \mathrm{mg} / \mathrm{d} l\right), 8(61.5 \%$ ) were over age 60 and $9(69.2 \%)$ had over $400 \mathrm{IU} / \mathrm{m} l$ of serum $\mathrm{IgE}$. These results demonstrate that serum $\mathrm{IgG}_{4}$ levels are associated with serum IgE levels in asthma patients over age 60 and are associated with patient age in all asthmatic subjects.

\section{References}

1) Ishizaka, $T$. : Analysis of triggering events in mast cells for immunoglobulin E-mediated histamine release. J. Allergy Clin. Immunol., $67: 90 \sim 96,1981$.

2) Tanizaki, Y., Komagoe, H., Sudo, M., Morinaga, H., Kitani, H., Goda, Y., Tada, S., Takahashi, K., Kimura, I. : IgE-mediated histamine release from whole blood in atopic asthmatics. Jpn J. Allergol., $32: 1079 \sim 1083$, 1983.

3) Tanizaki, Y., Komagoe, H., Morinaga, H., Kitani, H., Goda, Y., Kimura, I. : Allergenand anti-IgE-induced histamine release from whole blood. Int. Archs. Allergy Appl. Immunol., $73: 141 \sim 145,1984$.

4) Aalberse, R.C., Dieges, P.H., Knul-Bretlova, V., Vooren, P., Aalbers, M., van Leeuwen, J. : IgG 4 as a blocking antibody. Clin. Rev. Allergy, $1:$ 289 302, 1983.

5) Nakagawa, T., Miyamoto, T.: The role of $\mathrm{IgG}_{4}$ as blocking antibodies in asthmatics and bee keepers. Int. Archs. Allergy Appl. Immunol., $77: 204 \sim 205,1985$.

6) Djurup, R.: The subclass nature and clinical significance of the IgG antibody response in patients undergoing allergen-specific immmunotherapy. Allergy, 40:469 486, 1986.

7) Djurup, R., Malling, H.J.: High IgG $_{4}$ anti- body level is associated with failure of immunotherapy with inhalant allergens. Clin. Allergy, $17: 459 \sim 468,1987$.

8) Chernokhvostova, E.V., Kotova, T.S., German, G.P., Atovmian, O.I. : $\mathrm{IgG}_{4}$ antibodies in hay fever patients. Difference in $\mathrm{IgG}_{4}$ response to tree and grass pollen allergen. Int. Archs. Allergy Appl. Immunol., $92: 217 \sim 222$, 1990.

9) Gwynn, C.M., Morrison Smith, J., Leon Leon, G., Stanworth, D.R. : IgE and IgG subclass in atopic families. Clin. Allergy, $9: 119 \sim 123$, 1979.

10) Stanworth, D.R. : Immunochemical aspects of human $\mathrm{IgG}_{4}$. Clin. Rev. Allergy, $1: 183 \sim$ 195, 1983.

11) Merrett, J., Barnetson, R. St. C., Burr, M.L., Merrett, T.G. : Total and specific IgG antibody levels in atopic eczema. Clin. Exp. Allergy $56: 645 \sim 652,1984$.

12) Lilja, G.; Magnusson, C.G.M., Oman, H., Johansson, S.G.O. : Serum levels of IgG subclasses in relation to $\mathrm{IgE}$ and atopic disease in early infancy. Clin. Exp. Allergy, 20:407 413, 1990.

13) Pene, J., Rousset, F., Briere, F., Chretien, I., Bonnefoy, J.Y., Spits, H., Yokota, T., Arai, N., Banchereau, J. and de Vries, J. : IgE 
production by normal human lymphocytes is induced by interleukin 4 and suppressed by interferons gamma and alpha and prostaglandin $E_{2}$. Proc. Natl. Axad. Sci. USA, $85: 6880$ $\sim 6884,1988$.

14) Lundgren, M., Persson, U., Larsson, P., Magnusson, C., Smith, C.I.E., Hammarstrom, L., Secerinson, E. : Interleukin 4 induces synthesis of $\mathrm{IgE}$ and $\mathrm{IgG}_{4}$ in human B cells. Eur. J. Immunol., 19: 1311 1315, 1989.

15) Ishizaka, A., Sakiyama, Y., Nakanishi, M., Tanizawa, K., Oshika, E., Kojima, K., Taguchi, Y., Kandil, E., Matsumoto, S.: The inductive effect of interleukin-4 on $\mathrm{IgG}_{4}$ and IgE synthesis in human peripheral blood lymphocytes. Clin. Exp. Immunol., $79: 392 \sim$ 396, 1990.

16) Nüsslein, H.G., Winter, M., Träg, T., Kaldan, J.R. : Interleukin-4-induced IgG subclass and IgE secretion by mononuclear cells from atopic donors. Int. Archs. Allergy Appl. Immunol., 95: 257 260, 1991.

17) American Thoracic Society: Chronic bronchitis, asthma, and pulmonary emphysema. Am. Rev. Respir. Dis., 85：762 768, 1962.

18) Nakagawa, T., Takaishi, T., Sakamoto, Y., Ito, K., Miyamoto, T., Skvaril, F. : IgG 4 antibodies in patients with house dust-mite sensitive bronchial asthma: Relationship with antigen specific immunotherapy. Int. Archs. Allergy Appl. Immunol., 71 : 122 125, 1983.

19) Nakagawa, T., Takaishi, T., Miyamoto, T., Sugi, M., Ishige, M. : IgG 4 -enzyme-linked immunosorbent assay using an anti-human $\mathrm{IgG}_{4}$ monoclonal antibody. Jpn J. Allergol., $34: 277 \sim 283,1985$.

20) Mukoyama, T., Ichikawa, K., Baba, M., Nakagawa, T., Miyamoto, T. : Specific antibodies of $\mathrm{IgE}, \mathrm{IgG}$ and $\mathrm{IgG}_{4}$ to Dermatophagoides pteromyssinus and ovalbumin in atopic children. Jpn J. Allergol., $35: 166 \sim$ $170,1986$.

21) Engvall, E., Perlman, P. : Enzyme-linked immunosorbent assay, ELISA. III. Quantitation of specific antibodies by enzyme-linked antiimmunoglobulin in antigen-coated tube. J. Immunol., 109: 129 135, 1972.

22) Ostergaard, P.A. : Non-IgE mediated asthma in children. Acta Paediatr. Scand., $74: 713 \sim$ 719, 1985.

23) Aalberse, R.C., Gaag, R. van der, Leewen, J. van : Serologic aspects of $\mathrm{IgG}_{4}$ antibodies. I . Prolonged immunization results in an $\mathrm{IgG}_{4}-$ restricted response. J. Immunol., 130:722 726, 1983.

24) Magnusson, C.G.M., Cesbron, J.Y., Djurup, R., Capron, A., Johansson, S.G.O. : Raised serum $\mathrm{IgG}_{4}$ levels in patients with atopy and filariasis : application of an automated particlecounting immunoassay using monoclonal antibody. Int. Archs. Allergy Appl. Immunol., $81: 238 \sim 244,1986$.

25) Iskander, R., Des, P.K., Aalberse, R.C. : $\mathrm{IgG}_{4}$ antibodies in Egyptian patients with schistosomiasis. Int. Archs. Allergy Appl. Immunol., 66 : 200 207, 1981.

26) Del Prete, G., Maggi, E., Parronchi, P., Chrétien, I., Tiri, A., Machia, D., Ricci, M., Banchereau, J., de Vries, J., Romagrani, S. : IL-4 is an essential factor for the IgE synthesis induced in vitro by human $\mathrm{T}$ cell clones and their supernatants. J. Immunol., 140: 4193 4198, 1988.

27) Jabara, H.H., Acherman, S.J., Vercelli, D., Yokota, T., Arai, K., Abrams, J., Dvorak, A. M., Lavigne, M.C., Banchereau J., de Vries, J., Leung, D.Y.M., Geha, R.S. : Induction of IL4- dependent IgE synthesis and IL-5-dependent eosinophil differentiation by supernatants of a human helper $\mathrm{T}$ cell clone. $\mathrm{J}$. Clin. Immunol., $8: 437 \sim 446,1988$.

28) Yang X-D., de Weck, A.L., Stadler, B.M. : Effect of recombinant human interleukin-4 on spontaneous in vitro human IgE synthesis. Eur. J. Immunol., $18:$ 1699 1704, 1988.

29) Nüsslein, H.G., Spiegelberg, H.L. : Interleukin-4 induces both $\mathrm{IgG}_{4}$ and $\mathrm{IgE}$ secretion by peripheral blood B cells. J. Clin. Lab. 
Anal., $4: 414 \sim 419,1990$.

30) Merrett, J., Burr, M.L., Merrett, T.G. : A community servey of $\mathrm{IgG}_{4}$ antibody levels. Clin. Allergy, $13: 397 \sim 407,1983$.

31) Wraith, D.G., Merrett, J., Both, A., Yman, L., Merrett, T.G. : Recognition of food allergic patients and their allergens by the RAST technique and clinical investigations. Clin. Allergy, $9: 25 \sim 36,1979$.

32) Keller, M.A., Heiner, D.C., Kidd, R.M., Myers, A.S. : Local production of $\mathrm{IgG}_{4}$ in human colostrum. J. Immunol., 130:1654 1657, 1983. 